\title{
CORPOS TRANS! VISIBILIDADE DAS VIOLÊNCIAS E DAS MORTES
}

\author{
Fábio Henrique Lopes*
}

RESUMO: Este artigo analisa uma inegável realidade de nossa sociedade contemporânea brasileira, a violência e a morte dirigidas à população trans. Para reflexão, focaliza alguns dos casos publicados pela imprensa, sobretudo via internet. Essas manifestações de ódio e de abjeção contra a população trans são produtos, efeitos e condição de uma histórica matriz heterossexista, cissexista e transfóbica. O ódio praticado contra o corpo trans - corpo que borra fronteiras de um histórico feminino e masculino, que produz e exige novos significados para as identidades e para as perfomatividades de gênero - é materializado na e pela agressão, violência e crueldade que comumente caracterizam a prática aqui denunciada.

Palavras-chave: transgeneridade; corpo; violência; morte.

\begin{abstract}
This article analyzes an undeniable reality of our contemporary brazilian society, the violence and the death aimed at transgender population. For reflection, focuses on some of the cases published by the press, especially by internet. These manifestations of hate and abjection against the transgender population are products, and effects of a historical condition, heterosexist, cissexist and transfobic. The hate practiced against the trans-body - body that blurs borders of a male and female history, which produces and requires new meanings for the identities and gender - is materialized in and aggression, violence and cruelty that commonly characterize the practice here denounced.
\end{abstract}

Keywords: transgenderity; body; violence; death.

A título de introdução retomo um trecho do Manifesto Transgênero, publicado como parte de um estudo-denúncia de Jaqueline de Jesus (2014: p.11):

\begin{abstract}
(...) a cidadania trans e a identidade de gênero da população transgênero são vilipendiadas pelo Estado, por instituições, grupos e pessoas. Formadores de opinião, em todos os meios de comunicação, preservam o juízo de que os gêneros e suas expressões são desígnios puramente biológicos, traduzidos em termos de cromossomos, pênis e vaginas. $\mathrm{O}$ direito a adequação de seus registros civis é impedido, na ausência de Leis que reconheçam as demandas ou mesmo na presença de operadores do Direito contrários à livre expressão de gênero. $\mathrm{O}$ seu direito à vida é ferido cotidianamente, no país em que mais se matam pessoas trans no mundo.
\end{abstract}

\footnotetext{
*Professor Adjunto do Departamento de História da UFRRJ. Pesquisador do CNPq e FAPERJ. E-mail: lopesfh30@uol.com.br

Dossiê Transversos: O Corpo na História e a História do Corpo, Rio de Janeiro, v. 05; n. 05; Ano 02. dez. 2015.
} 
Denuncio, com o Manifesto acima, uma hedionda realidade de nossa sociedade contemporânea brasileira, a violência, a morte e o ódio dirigidos à população trans. Contudo, como ponto de partida para este exercício de reflexão, esclareço que os inúmeros casos de violência, de mortes e de ódio aqui focalizados são datados, efeitos e produtos da relação espaçotempo, possuindo, por isso, historicidades. Seus significados possuem determinadas e históricas condições de possibilidade, não tendo o mesmo sentido para todxs aquelxs com e nela envolvidxs. Na mesma direção, afirmo que os aviltantes números de assassinatos e homicídios, as cotidianas e naturalizadas manifestações de ódio e abjeção contra a população trans são produtos, efeitos e condição de uma histórica matriz heterossexista, cissexista e transfóbica.

Segundo Carrara e Vianna (2004: p. 365), apesar de já encontrarmos análises sobre violências contra homossexuais, as pesquisas brasileiras sobre a temática ainda são poucas e praticamente todos os dados sobre os quais se baseiam as aterradoras estatísticas sobre assassinatos de homossexuais (e transgêneros) no país provêm de notícias de jornal. Levantamento bibliográfico também revela práticas e padrões recorrentes no trato com a violência dirigida àquelxs que rompem com as normas, com os padrões e com os modelos heteronormativos e cissexistas: assassinatos, execução, crueldade, ódio, roubos, extorsões, desqualificação moral e culpabilização das vítimas, falta de empenho nas investigações policiais, responsabilização da vítima, em suma, exposição à morte e à violência cotidianas.

James Green (2000), por exemplo, identifica e analisa, desde pelo menos o final do século XIX, várias práticas e estratégias de vigilância, repressão e violência contra homossexuais. Reprovação social, escárnio, campanhas de repressão foram organizadas e orientaram projetos e ações contra homossexuais. Policiais, médicos, juristas e criminologistas participaram de verdadeiras cruzadas para controlar o "desvio" homossexual. Desde então, homossexuais afeminados foram atrelados à prostituição, à condição de passivos, de penetrados e, por isso, inferiorizados. Dessa maneira, a norma heterossexual foi reforçada pela constituição do sujeito "homossexual afeminado", assumindo o papel e a performance da mulher e do feminino, o outro do considerado "homem verdadeiro", ou seja, do penetrador. Uma mesma lógica binário, portanto, definia - e talvez ainda defina -, os gêneros masculino e feminino e que funcionava para forjar a distinção entre a heterossexualidade e a homossexualidade. Estratégias históricas de poder, de manutenção e de repetição da norma tradicional naturalizada como heterossexual.

Várias das associações e dos sentidos negativos historicamente atrelados às mulheres também foram agenciados na constituição do "homossexual afeminado" e, posteriormente, das pessoas trans. Vale a pena lembrar, segundo as pistas oferecidas por Green (2000), que por

Dossiê Transversos: O Corpo na História e a História do Corpo, Rio de Janeiro, v. 05; n. 05; Ano 02. dez. 2015. 
muito tempo a categoria "travesti" foi empregada para nomear os "homens vestidos de mulher", sobretudo durante o carnaval. Também não podemos esquecer que até 1940 o travestismo em público constituía uma violação do Código Penal. No Brasil, apesar da visibilidade alcançada pelos bailes de carnaval - e depois pelos dos shows de travestis -, a perseguição policial era um problema constante para os homossexuais e para as travestis cariocas entre as décadas de 1950 a 1970 (GREEN, 2000: p. 266).

Contudo, apesar das reflexões já concluídas e publicadas, há, ainda, um vasto campo a ser identificado, denunciado, analisado e explorado, o da transfobia, das discriminações, das agressões, das chantagens, das ofensas, das ameaças à vida e dos inúmeros casos de morte da população trans. Difícil campo a ser mapeado, aquele que, como indicam Ramos e Carrara (2006: p. 193), se constitui não só pelos crimes letais, mas também pelos crimes nãoespetaculares e não-letais, gerados e vividos em escala microssocietária, na esfera da família e de conhecidos.

No que diz respeito à violência, à morte, ao ódio e à abjeção direcionados às pessoas trans um desafio ainda deve ser enfrentado por todxs que se dedicam a esses temas ou são por eles incomodados e instigados a agir politicamente: o de ressaltar as especificidades das violências, do ódio, da morte e de suas implicações e de seus desdobramentos na vida e nas experiências das pessoas trans.

Para esta empreitada, começo refletindo sobre os casos de violência. Em primeiro lugar é preciso definir, mesmo que inicialmente, o que compõe isso que chamo de violência dirigida à população trans. Algumas pistas iniciais devem ser destacadas: as intolerâncias, desconforto diante da transgeneridade, roubos, agressão verbal, assassinatos sádicos e de requinte em crueldade, crimes de ódio, escárnio, apedrejamento, hostilidade, rejeição, constrangimento, recriminações, chacotas que provocam sentimentos de vergonha, ostracismo social, animosidades, estigmatização, assédio moral, violências hierárquicas, marginalização, agressão e ofensas pelo fato de ter aparência feminina. Processos e repetições que cristalizam sentidos, espaços, imagens e referências, que forjam realidades e experiências, participam, assim, de processos de subjetivação.

Essa diversidade de manifestações de violência é vivenciada por travestis e transexuais que se encontram num extremo da escala de vitimização e vulnerabilidade (RAMOS e CARRARA, 2006: p. 198). Elas constituem os grupos que vivem as experiências críticas de violência e que, portanto, devem exercer papel decisivo na demanda de políticas e na participação direta em práticas de prevenção (RAMOS e CARRARA, 2006: p. 199). Explicando melhor, "o grau de exposição a atos violentos separa muito nitidamente diferentes categorias - gays, lésbicas e 
travestis - frequentemente agrupados sob a genérica rubrica de homossexuais" (CARRARA e VIANNA, 2006: p. 234). Por exemplo, dados e pesquisam revelam que o tipo de violência letal que incide sobre travestis é bem diferente da que tende a atingir outros homens nãoheterossexuais. Mesmo entre as travestis vitimadas há predominância de negras e pardas, enquanto entre gays, ou seja, homossexuais que não exibem tão claramente as marcas de sua "diferença", predominam indivíduos classificados como brancos, com alta escolaridade e oriundos das camadas médias urbanas (RAMOS e CARRARA, 2006: p. 235).

De acordo com Monica Siqueira (2004: p. 70-71), entre as décadas de 50 e 70 do século $\mathrm{XX}$, as travestis no Rio de Janeiro sofriam severas retaliações se saíssem às ruas, principalmente da parte do poder público, que através de seu aparelho coercitivo policial restringia e tentava regular não somente as atividades de trottoir do grupo, mas também qualquer espécie de “aparição" desses sujeitos no cenário social.

Rodrigo Borba (2011: p. 199) apresenta algumas histórias de violência que evidenciam a vulnerabilidade social em questão. De acordo com ele, travestis mortas a tiros por transeuntes, ovos e pedra jogados das janelas dos carros, surras e outros tipos de humilhações são comuns nas narrativas das travestis. Por enfrentar todo tipo de violência nas ruas, as travestis parecem ter desenvolvido sofisticadas técnicas e performances para escapar de situações perigosas e, sempre que têm a oportunidade, trocam suas experiências e aprendizados para levar a vida na batalha com mais segurança.

Guacira Louro (2001: p. 542) ressalta que apesar da maior visibilidade das chamadas "minorias" sexuais, esta tem efeitos contraditórios: por um lado, alguns setores sociais passam a demonstrar uma crescente aceitação da pluralidade sexual e, até mesmo, a consumir alguns de seus produtos culturais; por outro lado, setores tradicionais renovam (e recrudescem) seus ataques, realizando desde campanhas de retomada dos valores tradicionais da família até manifestações de extrema agressão e violência física. Sobre essa questão, não posso deixar de citar os trabalhos de Siqueira (2009), Kulick (2008) e Pelúcio (2009), pois enfatizam os processos de estigmatização e de discriminação vivida pelas travestis em seus cotidianos em nossa sociedade contemporânea.

Mas algumas questões continuam sem respostas e precisam ser sublinhadas para o debate que proponho: como as distintas formas e tipos de violência participam da noção, da compreensão e dos sentidos da transgeneridade? Por que a violência é considerada um correlato do sexo trans? Como tal correlação funciona? Qual a base dessa articulação? O que ela agencia? O que silencia, exclui e/ou apaga? Como a violência foi vista, sentida, percebida e vivenciada pela 
população trans? O que forjou? Como se organiza a explicação da experiência da violência pelas transgêneros? Qual o impacto que as violências contra a população trans têm sobre suas vidas? Como lidaram (ou lidam) com o espectro cotidiano da violência e da morte? Como as experiências, os sentidos e as imagens das violências praticadas contra as trans moldaram existências, modos de vida e de resistências? Posso afirmar que as distintas formas e tipos de violências contra as pessoas trans (da violência física às tentativas de invisibilização e apagamento; das injúrias e dos xingamentos às caricaturas e representações inferiorizantes; dos sarcasmos ao ódio) instauram e organizam as experiências trans? Instauram e/ou possibilitam históricos modos diferenciados de existência diferenciados?

Não é possível responder todas essas questões neste artigo. Por isso, opto por identificar, denunciar e analisar alguns dos casos publicados pela imprensa, sobretudo via internet, encontrados em pesquisa de fonte e documental. Esses casos foram selecionados porque indicam e reiteram o ódio heterossexista, cissexista e transfóbico, além das mortes praticadas contra a população trans no Brasil.

Heterossexismo, heterossexualidade compulsória e heteronormatividade são categorias que auxiliam a desnaturalizar uma hegemonia que é historicamente instituída: a hegemonia heterossexual. Nas palavras de Judith Butler (2008: p. 99), a imposição da heterossexualidade compulsória na descrição dos corpos, por exemplo - e eu acrescento, na espetacularização da morte, na considerada derrota e na punição trans, na almejada vitória e vingança heterossexuais contra aquelxs que ousam transpor o gênero instituído - produz o sexo de acordo com uma morfologia heterossexual. Ainda segundo Butler (2008: p. 105), tecnologias políticas que são diferencialmente distribuídas para salvar algumas vidas e para condenar outras à morte. Morte considerada culturalmente como consequência lógica de uma vida trans, como preço e como castigo a ser pago pelo desejo diferente, morte que já estava presente nos bastidores, já anunciada (BUTLER, 2008: p. 105-6).

Meu desafio é não mais problematizar os tipos de violências e de morte contra as pessoas trans para evidenciar apenas o trágico. Tampouco naturalizar a marginalidade e a criminalidade como referências próprias e indispensáveis constituintes da transgeneridade. O desafio é maior, o de desnaturalizar, problematizar e denunciar a linguagem performativa que institui sentidos. Linguagem historicamente possibilitada que forja processos de subjetivação, normatização e controle. Dessa maneira, pela linguagem e pelo discurso é possível não só reforçar a hegemonia heterossexual e cissexista, como também afirmar e propor desestabilizações e subversões na e da matriz heterossexual e cissexista.

Dossiê Transversos: O Corpo na História e a História do Corpo, Rio de Janeiro, v. 05; n. 05; Ano 02. dez. 2015. 
Algumas pistas para complexificar o uso da linguagem e dos discursos serão, a partir desse ponto, ressaltados. Em outubro de 2010, o site portalsida publica a nota:

\begin{abstract}
Por favor, Não nos MATEM !! Sangue das Travestis assassinadas no Estado formam um Rio de Transfobia !

Os constantes casos de TRANSFOBIA no Brasil, vem ganhando significativa contribuição oriunda do nosso Estado, nos últimos 2 meses, foram contabilizados por esta instituição o trágico número de SETE Travestis assassinadas em diferentes regiões do Rio de Janeiro. O protagonismo absoluto das Travestis e Transexuais nas estatísticas de todas as pesquisas realizadas sobre violência e discriminação sofrida entre a população LGBT no Brasil, vem agravando-se desde o final de 2009.

(...) no dia 22/04/2010 "Romana" uma jovem Travesti foi assassinada a pauladas na cabeça no bairro Califórnia em Nova Iguaçu, no dia 30/04/2010 a Travesti "Renata" foi assassinada também por espancamento no bairro Jardim Tropical, dia 05/05/2010 a Travesti "Sheila" assassinada com 20 tiros no bairro Jardim Aurora depois da UNIG em Nova Iguaçu, dia 17/05/2010 a Travesti "Cesar Henrique Vendrame" espancado violentamente até a morte no bairro Paraíso em Resende, dia 23/05/2010 a Travesti "Taila (José D. B. dos Santos Júnior)" natural de Itabuna - BA e residente na Lapa foi assassinada e teve o corpo carbonizado pelo universitário e lutador Leonardo Loeser no bairro Jardim Botânico, zona sul da capital do RJ (... $)^{1}$
\end{abstract}

O trecho acima é rico em possibilidades de reflexão e análise. Destaco, inicialmente, a agressividade, o ódio e a abjeção direcionados às pessoas trans, a seus corpos que foram agredidos, mutilados e marcados. Nos e pelos corpos, moldados a partir de uma determinada referência de feminilidade, seguindo padrões também históricos de beleza e de comportamento, o ódio e a abjeção são materializados.

Talvez o mesmo grau de ódio e de abjeção praticado em outro extermínio:

\title{
Travesti é morto a facadas em Campina Grande - PB
}

Um travesti foi morto na madrugada da última sexta-feira, 15 , após ser esfaqueada por dois rapazes em Campina Grande (PB). O crime foi registrado por câmeras de monitoramento da Superintendência de Trânsito da cidade. Um menor de 17 anos confessou ontem a responsabilidade pelo crime, que teria cometido por vingança.

Segundo a delegada Cassandra Duarte, o vídeo mostrava um veículo preto se aproximando do local onde estava o travesti. Dois dos quatro ocupantes desceram do carro e desferiram mais de 30 facadas contra ele após agredi-lo com chutes $(. . .)^{2}$

O ódio praticado contra o corpo trans - corpo que borra fronteiras de um histórico feminino e masculino, que produz e exige novos significados para as identidades e as perfomatividades de gênero - é materializado na e pela agressão. No aterrador número de facadas, de tiros, de chutes e de socos que sugere algo mais do que o desejo de matar:

1 Disponivel em: 〈htttp://www.portalsida.org/news_details.aspx?ID=10690〉. Acesso em: 08 out. 2013.

2 Disponivel em: <http://www.territorioeldorado.limao.com.br/noticias/not112302.shtm〉. Acesso em: 18 nov. 2013.

Dossiê Transversos: O Corpo na História e a História do Corpo, Rio de Janeiro, v. 05; n. 05; Ano 02. dez. 2015. 


\section{Após crime, travestis de Teresina prometem agir com violência}

Após mais caso de violência contra os travestis, a revolta entre eles tornou-se generalizada, Na última quinta-feira (19), Edson Carlos da Silva Sousa, mais conhecido como 'Lorrane' foi encontrado com perfurações pelo corpo e indícios de luta corporal, embaixo da ponte no bairro Tabuleta, na zona sul de Teresina.

No último mês de maio, outro travesti identificado por 'Claudia Flash' foi vítima de violência, Ele foi arrastado, espancado e assassinado com dois tiros, também na zona sul da capital. Há cerca de um ano, dias após a Parada da Diversidade de Teresina, "Cinara" foi encontrada morta em uma horta do bairro Dirceu Arcoverde. A vítima foi amordaçada e além de espancamentos, recebeu 53 facadas. $^{3}$

Além do ódio materializado na agressão excessiva das 30 ou 53 facadas acima mencionadas, outro fator deve ser ressaltado, a escolha dos lugares onde os corpos foram jogados. No lugar de ser aleatória, a escolha participa do processo de subalternização, regulação e controle de modos de vida. Ao mesmo tempo, indica o sentido atribuído à morte praticada:

\section{Travesti tem pênis cortado e é atirado em fossa em Alagoas}

Dois homens foram presos em flagrante na manhã deste sábado depois de agredir um travesti, no conjunto Guriatã, na cidade de Rio Largo (AL), na região Metropolitana de Maceió. Segundo a Polícia Militar, os homens cortaram o pênis da vítima e a jogaram em uma fossa com aproximadamente 10 metros de profundidade. (...) Após o resgate, os PMs localizaram os dois agressores, Gilberto da Silva, 30 anos, e Claudio Roberto Alves de Oliveira. Eles estavam dormindo em uma casa, próxima ao local onde a vítima foi jogada. ${ }^{4}$

$\mathrm{O} / \mathrm{a}$ leitor/a mais atento deve ter notado que os casos até agora selecionados sugerem que a violência, o ódio e a morte praticados e dirigidos à população trans é um fenômeno nacional. Não nego com isso as especificidades regionais e locais, mas é inquestionável a amplitude da prática da abjeção, observada e vivenciada em vários Estados e cidades do país. Inspirado pelas provocações de Butler, posso afirmar que do Nordeste brasileiro à região Sul, encontramos a morte entendida como compensação necessária para o desejo transgênero (2008: p. 106):

\section{Outro travesti é assassinado em Curitiba}

Mais um travesti foi brutalmente assassinado em Curitiba... O corpo foi encontrado por volta das $11 \mathrm{~h}$ de ontem, caído em meio a um amontoado de entulho de lixo próximo à entrada do Parque Náutico e à ponte do Rio Iguaçu.

A vítima estava com a calcinha na altura dos joelhos e foi atingida por três tiros, o rosto foi desfigurado. Ao lado do corpo, peritos do Instituto de Criminalística recolheram alguns cartuchos de pistola calibre $380 \ldots$

\section{Outro}

No dia anterior, outro travesti foi morto violentamente. O corpo de João Leandro Rosário dos Santos, 26 anos, conhecido como "Natasha" foi encontrado no canteiro da

3 Disponível em: <htttp://www.piauinet.com.br/policia/após-crime-travestis-de-teresina-prometem-agir-com-violencia48442.html>. Acesso em: 09 out. 2013.

4 Disponível em: <htttp://www.emaisgoias.com.br/noticiais/Brasil/2013/7/18/37146.html?Travesti+tem+penis ${ }^{+}$cortado $+\mathrm{e}^{+} \mathrm{e}^{+}$atirado+em+fossa+em+Alagoas++>. Acesso em: 08 out. 2013.

Dossiê Transversos: O Corpo na História e a História do Corpo, Rio de Janeiro, v. 05; n. 05;

Ano 02. dez. 2015. 
Avenida Juscelino Kubitschek, Vila Santa Helena, na Cidade Industrial. Ele foi assassinado com pedradas na cabeça. ${ }^{5}$

O site acima, além de noticiar a morte, oferece a espetacularização, transformada em castigo ou culpa, do corpo abjeto depositado no único lugar a eles reservado, ou seja, no meio dos entulhos e do lixo:

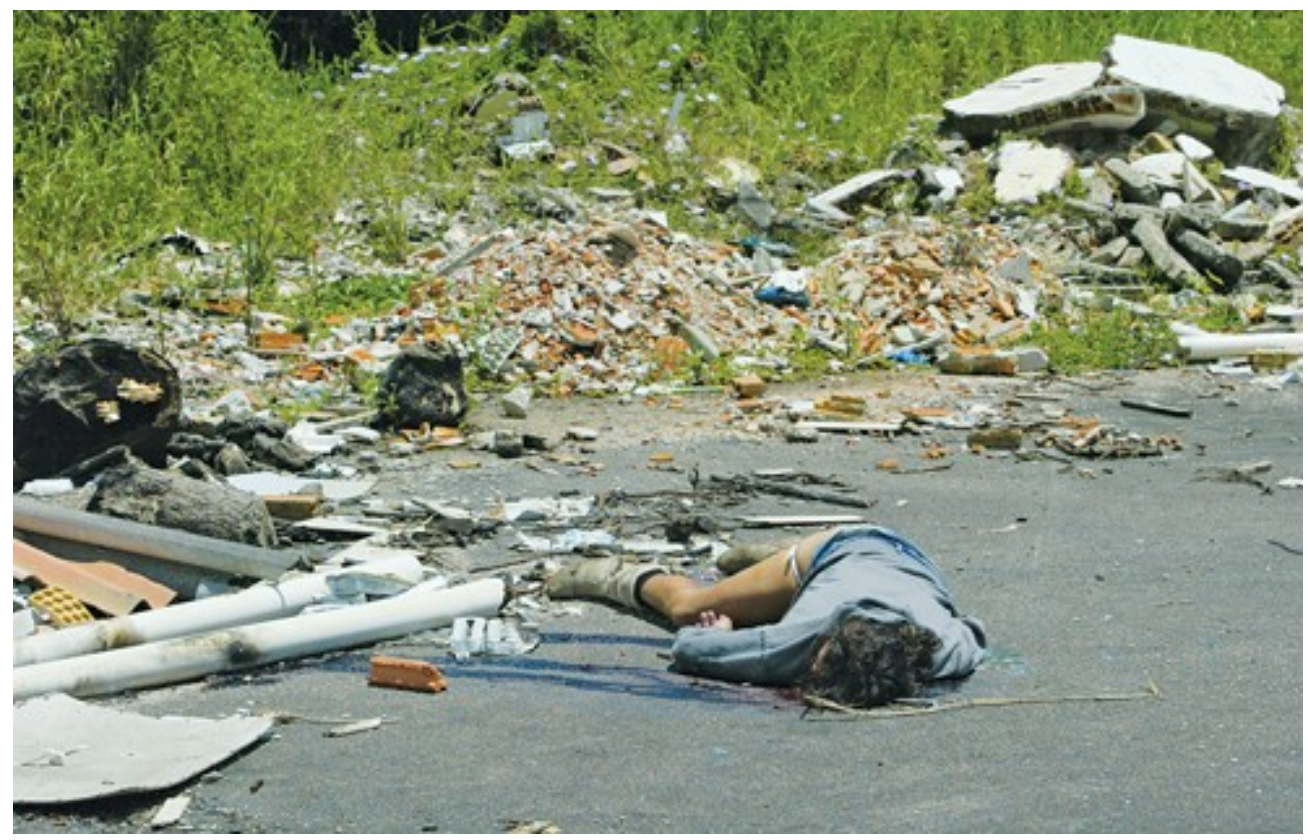

Ilustração $1^{6}$

Outros dois casos apontam a morte cruel e violenta como resultado socialmente esperado, e talvez desejado, por nossa sociedade ainda moldada por sistemas e tecnologias políticas machistas, misóginas, transfóbicas e cissexistas:

\section{Travesti encontrada degolada e seminua}

Corpo foi encontrado no terreno da casa da vítima

Uma travesti de 19 anos foi encontrada degolada no quintal de sua casa, em Camapuã, norte do Estado [Mato Grosso do Sul]. Seu nome de registro era Luciana da Silva, mas era conhecida como Ágata. Ela recebeu uma facada na área próxima ao coração, e segundo a perícia, lutou contra seu assassino e tentou escapar, sendo então degolada. ${ }^{7}$

\section{Continuo:}

5 Disponível em: <htttp://pron.com.br/editoria/policia/news/507414/?noticia+OUTRO+TRAVESTI+E+ ASSASSINADO+EM+CURITIBA>. Acesso em: 07 out. 2013.

6 Disponível em: < http://www.parana-online.com.br/editoria/policia/news/507414/?noticia=OUTRO+TRAVES TI +E+ASSASSINADO+EM+CURITIBA>. Acesso em: 07 out. 2013.

7 Disponível em: <htttp://www.contextog.com.br/noticiais/violência/travestia-encontrada-degolada-e-seminua140.html>. Acesso em: 04 out. 2013.

Dossiê Transversos: O Corpo na História e a História do Corpo, Rio de Janeiro, v. 05; n. 05; Ano 02. dez. 2015. 


\section{TRAVESTI DENUNCIA AGRESSÃO DE PMS EM STO ANDRÉ}

Avenida Industrial, Santo André, madrugada dos dias 3, 5 e 7 de janeiro. Enquanto dormiam, travestis que vivem em uma fábrica abandonada, em frente a um condomínio de luxo e hotéis de alto padrão, foram agredidos violentamente com socos, chutes, coronhadas, pancadas e vigas de ferro.

Também foram ameaçadas de morte, além de terem suas moradias precárias queimadas e destruídas. O fogo não poupou nem um botijão de gás utilizado pelos moradores, embora não tenho ocorrido explosão, As vítimas garantem que autores foram seis policiais militares, que estavam fardados.

(...) Os travestis afirmam que a violência foi gratuita, já que nenhuma justificativa foi dada para as agressões. Nem o cachorro de estimação de um casal de travestis foi poupado: os agressores queimaram o animal. $\mathrm{O}$ travesti Jully foi jogado do segundo andar de um pequeno sobrado.

"Eles me mandaram descer correndo, estava muito assustado. Não dava para ver nada, quando um dos policiais me deu um empurrão e gritou 'voa bicha'. Estou com muito medo, não quero morrer", disse Jully. ${ }^{8}$

Para complexificar a articulação entre ódio, violência, heteronormatividade e transgeneridade sigo as pistas apresentadas por Christine Greiner. As dizibilidades e visibilidades até aqui apresentadas expõem o outro, a outridade, que deflagra a exposição à violência e à morte (GREINER, 2007: p. 12), revelando, assim, nossa incapacidade em reconhecer e em lidar com a alteridade e com o outro. De acordo com a autora, trata-se de violência com dimensão performativa, porque precisa ter público, nem que o público seja apenas a própria vítima.

Aproximando-se das considerações de Greiner, diversos estudiosxs que se apropriam das teorias queer denunciam a estilização da violência transfóbica registrada, marcada e comprovada no corpo trans encontrado em latas de lixo, em fossas e em lixões. Vidas encurtadas pelo ódio e pela abjeção, corpos mortos historicamente oferecidos e naturalizados como prova da hegemonia e do poder heterossexual! Atos repetidos de violência, assassinatos e extermínio que buscam justificativas e querem ser justificados em uma histórica pressuposição, a da heterossexualidade compulsória, que molda e define modos de viver, de morrer e de exterminar o outro.

Travesti natural de Luis Correia é assassinado em Parnaíba com tiro no peito.

O transformista Joales dos Santos, de 22 anos, natural da localidade Brejinho, zona rural de Luis Correia, que residia a rua Delbão Rodrigues, n. 304, bairro São Francisco da Guarita, foi assassinado com um tiro a queima roupa atingindo o peito esquerdo. ${ }^{9}$

A notícia acima poderia ser mais uma entre tantas que aparecem em pesquisa realizada na imprensa ou na internet sobre violência e morte da população trans no Brasil. Contudo, o que chama a atenção é o amplo recurso das imagens do corpo morto estendido no chão, outra prova da morte, da espetacularização do castigo, da vingança e da crueldade heterossexual e cissexista:

8 Disponivel em: <htttp://www.abcdmaior.com.br/noticia_exibir.php?noticia=5051 >. Acesso em: 07 out. 2013. 9 Disponível em: <htttp://www.blogwiltonveras.com/201308/travesti-de-luis-correiae.html>. Acesso em: 09 out. 2013.

Dossiê Transversos: O Corpo na História e a História do Corpo, Rio de Janeiro, v. 05; n. 05; Ano 02. dez. 2015. 


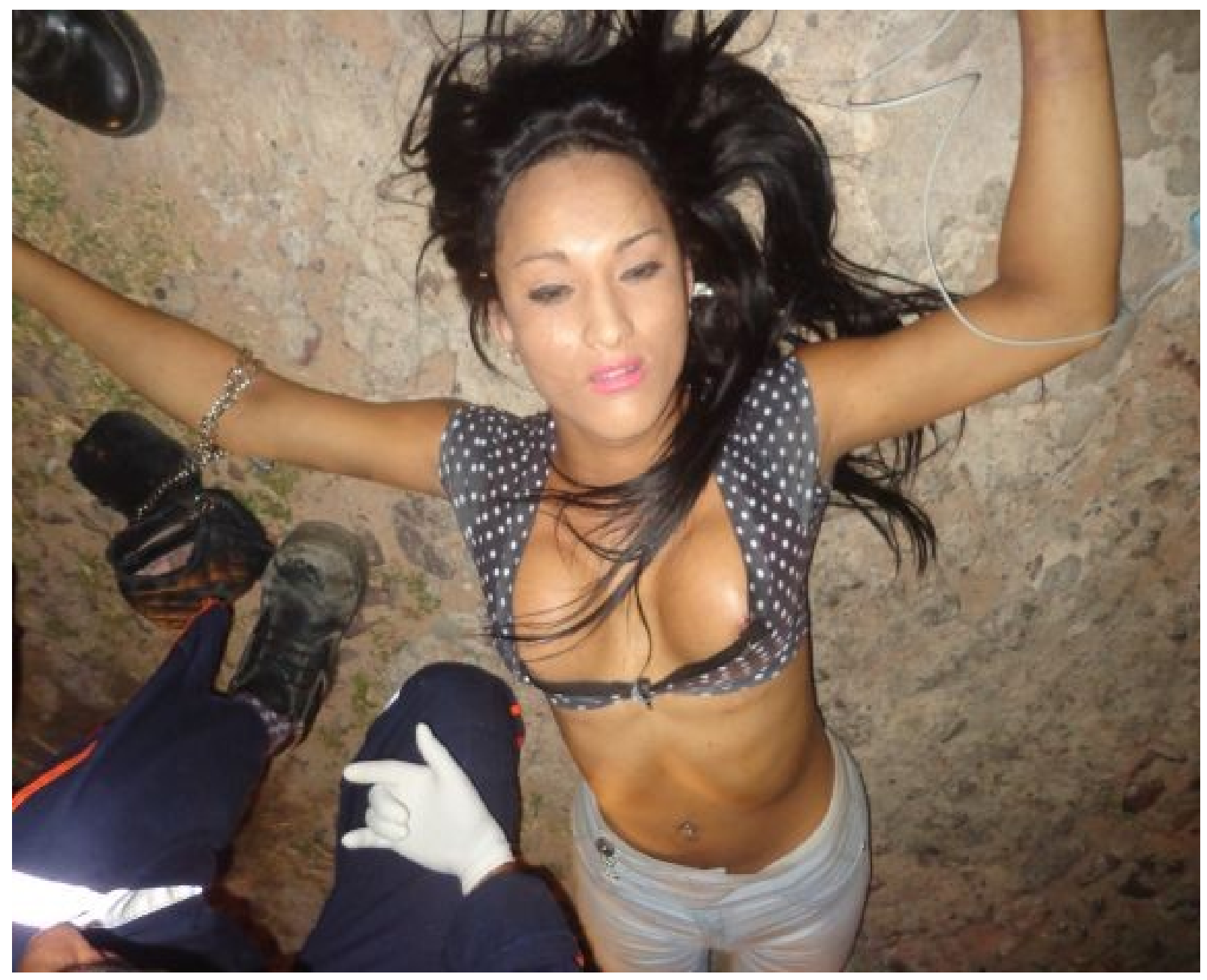

Figura $2^{10}$

10 Disponível em: <htttp://www.blogwiltonveras.com/201308/travesti-de-luis-correiae.html〉. Acesso em: 09 out. 2013.

Dossiê Transversos: O Corpo na História e a História do Corpo, Rio de Janeiro, v. 05; n. 05; Ano 02. dez. 2015. 


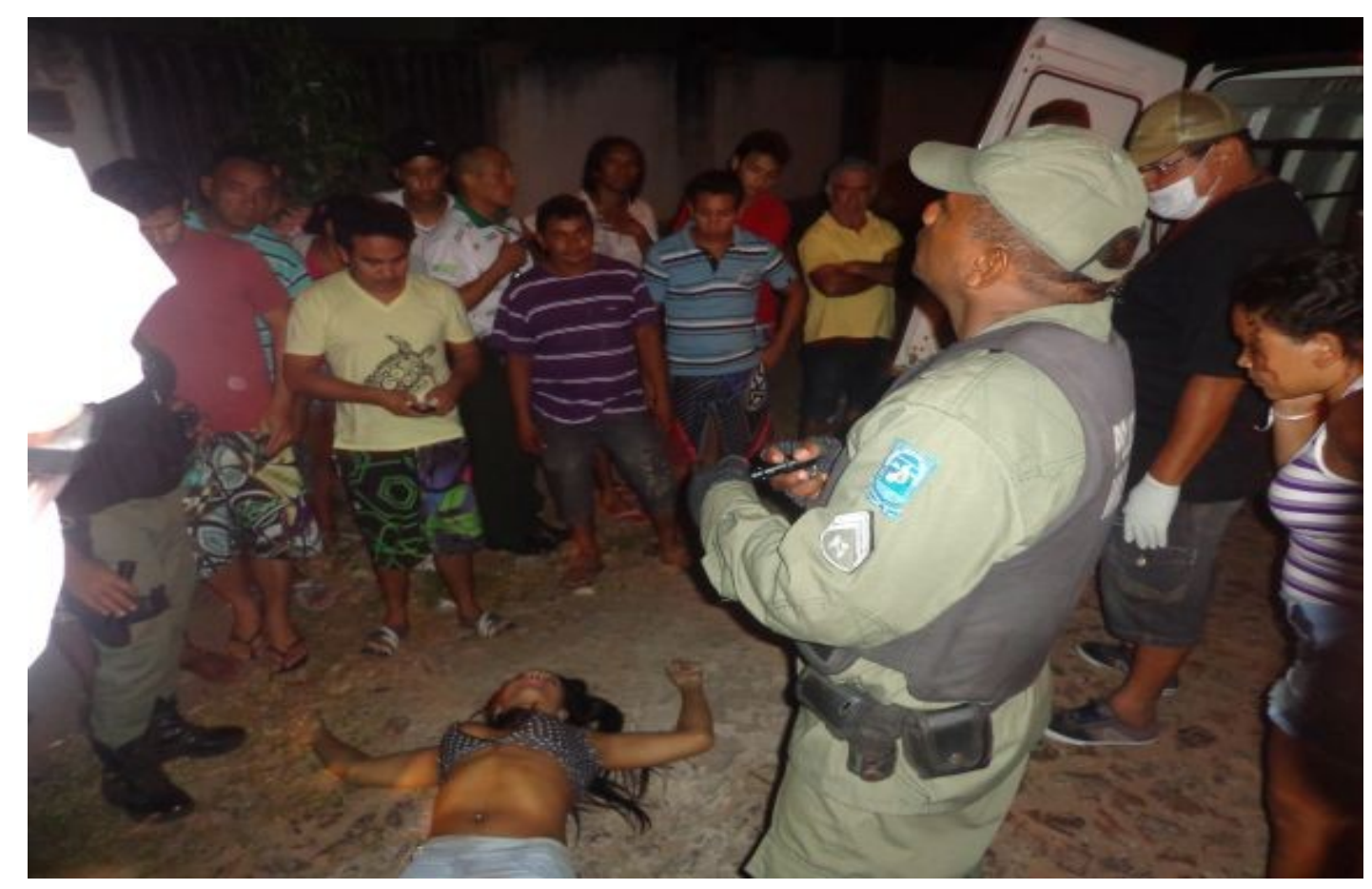

Figura $3^{11}$

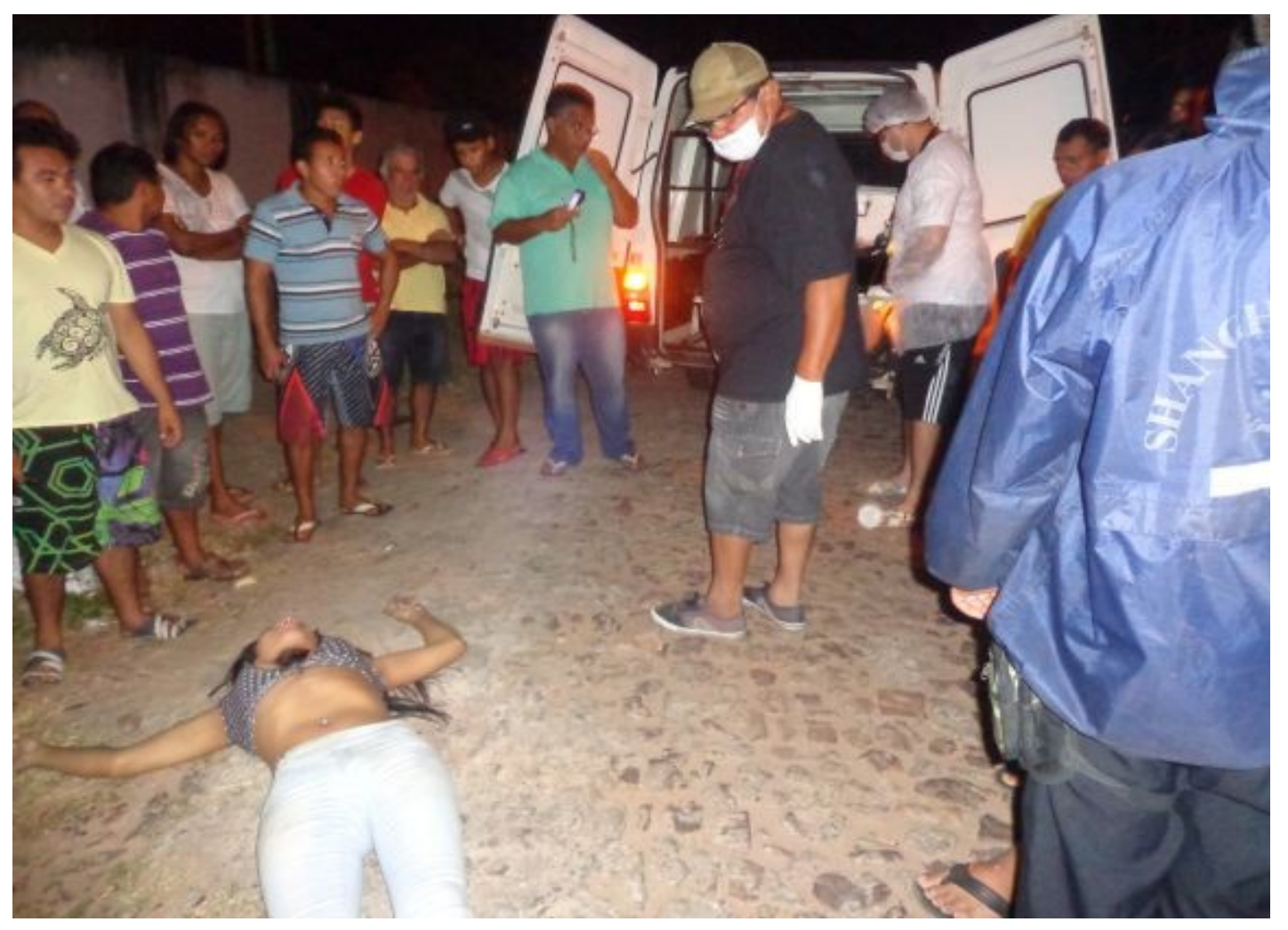

Figura $4^{12}$

11 Disponível em: 〈htttp://www.blogwiltonveras.com/201308/travesti-de-luis-correiae.html〉. Acesso em: 09 out. 2013.

12 Disponivel em: 〈htttp://www.blogwiltonveras.com/201308/travesti-de-luis-correiae.html〉. Acesso em: 09 out. 2013.

Dossiê Transversos: O Corpo na História e a História do Corpo, Rio de Janeiro, v. 05; n. 05; Ano 02. dez. 2015. 
Notem nas imagens acima o fascínio e a apreciação pública do corpo estendido, da morte praticada, do ódio materializado. Do foco e da centralidade direcionados ao rosto e aos seios, revelando os cuidados na produção de uma determinada e histórica feminilidade, potencializada pelo uso da maquiagem, pela vestimenta e pelos utensílios de moda, dos olhos dos espectadores voltados ao corpo estendido no chão e com os abraços abertos, à presença dos policiais vigiando a morte, e não garantindo a vida e ao maior número de homens na cena acima, elementos que compõem um aterrador ritual. Espetacularização presente em vários outros casos:

Travesti é morto com vários tiros em Olinda

Polícia ainda não sabe o que motivou o crime

Mais um travesti foi vítima da violência no Grande Recife, Leandro Eduardo Campos Ferreira, o Léo, de 25 anos, foi morto com vários tiros, na noite desta quinta-feira (26)... De acordo com informações da polícia, a vítima estava jogando dominó em um bar com alguns amigos quando dois homens chegaram em uma moto e efetuaram os disparos... ${ }^{13}$

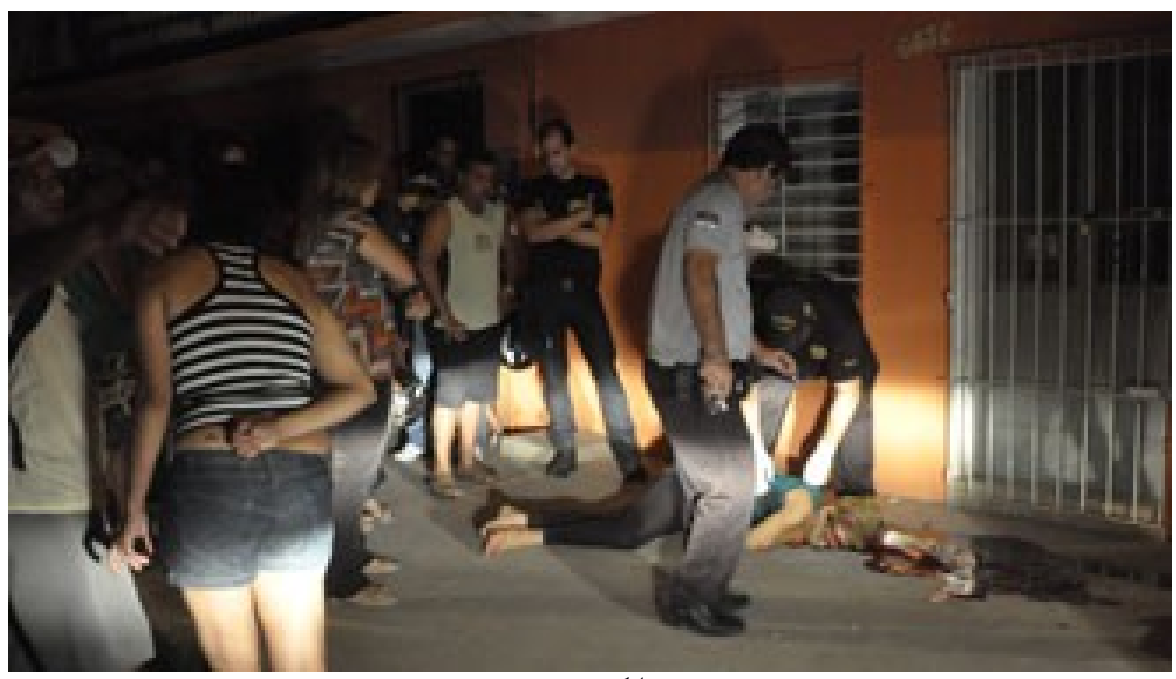

Figura $5^{14}$

Pela materialidade do ódio comprovada pela crueldade das agressões e pela divulgação recorrente das imagens dos corpos estendidos no chão, ou depositados em lixões e valas, a morte trans revela as hierarquizações, a precarização e subalternização de certas vidas, tornando as pessoas trans menos humanas. Nas palavras de Judith Butler (2008: 95), morte e fim de um modo específico de vida, a vida trans. Não quero com isso naturalizar o que chamo de "vida trans", ou mesmo o que defino como "corpo trans". O objetivo é exatamente o oposto, ou seja,

13 Disponível em: <htttp://www.folhape.com.br/cms/opencms/folhape/PT/cotidiano/policiaarquivos/2011 outubro/0522html>. Acesso em: 09 out. 2013.

14 Disponível em: <htttp://www.folhape.com.br/cms/opencms/folhape/PT/cotidiano/policiaarquivos/2011 outubro/0522html>. Acesso em: 09 out. 2013.

Dossiê Transversos: O Corpo na História e a História do Corpo, Rio de Janeiro, v. 05; n. 05;

Ano 02. dez. 2015. 
trago elementos de um dispositivo, de uma matriz, de uma rede de inteligibilidade política, social, cultural e histórica que administram e regulamentam modos de vida e subjetivações. Regimes discursivos e institucionais, ordem discursiva que instauram vontades de verdade, asseguram exercícios de poder e hierarquizam os gêneros.

Nas fontes apresentadas neste breve exercício de reflexão, entendido como um posicionamento acadêmico, cultural e política, a morte e o morrer foram inventados e narrados no e pelo cruzamento de normas, assujeitamentos, governamentalidades, disciplinas, vigilâncias e subjetivações. Enunciados, saberes, discursos, relações de saber-poder são forjados e oferecidos em meios de divulgação, impressos ou digitais, que dotam de sentido e de significado os gestos, os desejos e os corpos. Informam e regulamentam, controlam e disciplinam modos de vida ao provocarem a morte, ou seria melhor dizer, ao provocarem um tipo específico de morte, aquela moldada pelo ódio, pela crueldade e pela abjeção.

Denuncio, portanto, a historicidade das recorrentes e cotidianas violências praticadas contra a população trans para dar visibilidade à desqualificação e ao ódio direcionados aos modos de vida, aos desejos, às identidades e às subjetividades que ameaçam a coerência do sistema sexo/gênero, que desmascaram os binarismos que sexualizam os corpos. Processos históricos de desqualificação e de hierarquização que são cotidianamente repetidos e reiterados pela "maquinaria heterossexual" que estigmatiza modos de vida e invenção se si como antinaturais, anormais e abjetos em benefício da estabilidade das práticas de produção do natural (PRECIADO, 2014: p. 30).

A proposta final é desnaturalizar a diferença e, assim, fraturar as diversas opressões conectadas aos modos de vida e à morte.

\section{Referências Bibliográficas}

BORBA, Rodrigo. Narrativas orais e (trans)masculinidade: (re)construções da travestilidade (algumas reflexões iniciais). Bagoas. n. 06, 2011, p. 181-210.

BUTLER, Judith. Corpos que pesam: sobre os limites discursivos do sexo. In: LOURO, Guacira (org.). O corpo educado: pedagogias da sexualidade. Belo Horizonte: Autêntica, 2001, p. 151172.

Problemas de Gênero: feminismo e subversão da identidade. Rio de Janeiro: Civilização Brasileira, 2003.

Dossiê Transversos: O Corpo na História e a História do Corpo, Rio de Janeiro, v. 05; n. 05; Ano 02. dez. 2015. 
.Inversões Sexuais. In: PASSOS, Izabel C. Friche (org.). Poder, Normalização e violência. Incursões foucaultianas para a atualidade. Belo Horizonte: Autêntica Editora, 2008, p. 91 - 108. CARRARA, Sérgio; SIMÕES, Júlio Assis. Sexualidade, cultura e política: a trajetória da identidade homossexual masculina na antropologia brasileira. Cadernos Pagu. (28), janeiro-junho de 2007: 65-99.

CARRARA, Sérgio; VIANNA, Adriana R.B. “Tá lá o corpo estendido no chão...”: a Violência Letal contra Travestis no Município do Rio de Janeiro. PHYSIS: Rev. Saúde Coletiva, Rio de Janeiro, 16 (2): 233-249, 2006.

CARRARA, Sérgio; VIANNA, Adriana R.B. "AS VÍTIMAS DO DESEJO”: Os tribunais cariocas e a homossexualidade nos anos 1980. In: PISCITELLI, Adriana; GREGORI, Maria Filomena; CARRARA, Sérgio (orgs.). Sexualidade e Sabres: convenções e fronteiras. Rio de Janeiro: Garamond, 2004, p. 365-383.

ERIBO, Didier. Reflexões sobre a questão gay. Tradução Procopio Abreu. Rio de Janeiro: Companhia de Freud, 2008.

GREEN, James. Além do Carnaval: a homossexualidade masculina no Brasil do século XX. São Paulo: Editora Unesp, 2000.

JESUS, Jaqueline Gomes de. Interlocuções teóricas do pensamento transfeminista. In:

Transfeminismo: teorias e práticas. Rio de Janeiro: Metanoia, 2014, p. 3-18.

KULICK, Don. Travesti: prostituição, sexo, gênero e cultura no Brasil. Tradução Cesar Gordon. Rio de Janeiro: Ed. FioCruz, 2008.

LOURO, Guacira Lopes. Teoria queer - uma política pós-identitária para a educação. Estudos Feministas. 2/2001, 541-553.

Marcas do corpo marcas do poder. In: Um corpo estranho. Ensaios sobre sexualidade e teoria queer. 1 ed., 1 reimp. - Belo Horizonte: Autêntica, 2008, p. 75 - 90.

PELÙCIO, Larissa Maués. Abjeção e desejo: uma etnografia travesti sobre o modelo preventivo de AIDS. São Paulo: Annablume; Fapesp, 2009.

PERES, Wiliam. Travestis: subjetividades em construção permanente. In: UZIEL, Anna; RIOS, Luís; PARKER, Richard (org.). Construções da sexualidade: gênero, identidade e comportamento em tempos de AIDS. Rio de Janeiro: Pallas, 2004, p. 115-128. 
Travestilidades nômades: a explosão dos ninarismos e a emergência queering. Estudos Feministas. Florianópolis, 20(2): 539-547, maio-agosto/2012.

PRECIADO, Beatriz. Manifesto contrassexual. São Paulo: n-1 edições, 2014.

RAMOS, Silvia; CARRARA, Sérgio. A constituição da problemática da violência contra homossexuais: a articulação entre ativismo e academia na elaboração de políticas públicas. PHYSIS: Rev. Saúde Coletiva, Rio de Janeiro, 16 (2): 185-205, 2006.

SIQUEIRA, Mônica Soares. Sou Senhora. Um estudo antropológico sobre travestis na velhice. 2004. 156f. Dissertação (Mestrado em Antropologia Social). Universidade Federal de Santa Catarina. Florianópolis, Santa Catarina.

Arrasando Horrores! Uma etnografia das memórias, formas de sociabilidade e itinerários urbanos de travestis das antigas. 2009. 494f. Tese (Doutorado em Antropologia Social). Universidade Federal de Santa Catarina. Florianópolis, Santa Catarina.

\section{Como citar:}

LOPES, Fabio Henrique. Corpos trans! Visibilidade das violências e das mortes. Revista Transversos. “Dossiê: O Corpo na História e a História do Corpo". Rio de Janeiro, Vol. 05, nº. 05, pp. 08-22, Ano 02. dez. 2015. Disponível em: 〈http://www.e-publicacoes.uerj.br/index.php /transversos >. ISSN 2179 . 7528. DOI: 10.12957/transversos.2015.19793. 